\title{
Catalogue of Map Artists
}

\section{Compiled by Denis Wood, Independent Scholar, Raleigh, NC}

This catalogue is largely based on the contents of ten map art exhibitions, as well as on a handful of books that deal with a significant number of map art pieces. Though it is without question the most extensive catalogue of map artists so far published, it makes no pretense of being complete. Its role is to document the fact that a lot of artists work with maps, and to provide a foundation for the work that remains to be done.

The artists have been arranged alphabetically. Where we have been able to determine these, we have provided, in parentheses, where the artist lives/works now or predominantly (in any event, not the place of birth or nationality), followed by the date of birth (and where appropriate, death). There is a brief description of artist's work, followed by a key to the sources. These are listed at the end of the catalogue.

Only the lightest culling has been attempted, but artists working today with but a single known piece of map art in their oeuvre have been less likely to be included than those with many or than those artists of the relative past whose work may have influenced the work of those active today.

As a work in progress, all additions, corrections, emendations, and suggestions are welcome, and may be addressed to either of the editors or any of the authors.

1) Australian Aboriginal paintings - (Australia, ...) raise all kinds of questions: are they maps? are they art? They are unquestionably beautiful artifacts, are currently sold in art galleries, and are widely regarded as maps. Individual map artists such as Polly Napangardi - who painted Wild Orange and Bilby Dreaming (1987) - or Barbara Weir - who painted My Mother's Country (1997) - undoubtedly deserve individual artist entries.

2) Walter Anderson - (Mississippi, 1903-1965) painted at least the Map of Horn Island (c. 1960): 18

3) Art and Language [Terry Atkinson/ Michael Baldwin/ others] - (Britain, 1939- , 1945- ), a widely influential British Conceptual Art collaborative, in 1967 made the Map to not indicate ..., where the ellipsis here indicates a long list of places not shown on the lithograph where, however, you do find Iowa and Kentucky. Art and Language described two other maps: Map of a thirty-six square mile surface area of the Pacific Ocean west of Oahu, and Map of itself. All three maps were apparently made by Atkinson and Baldwin, but prior to the founding of Art and Language: 6, 10, 11, 17

4) Lisa Austin - (Maryland, ... ) exploits "the poetry" of maps in installations such as My Maryland: 9

5) Mojdeh Baratloo and Clifton J. Balch - (..., ...) produced ANGST: Cartography, initially in 1982 (for a group exhibition, The Monument Redefined), in 1988 (for an exhibition at New York's at P.S. 1), and in 1989 (as a book published by SITES/Lumen, New York); with photos, images of Gowanus Canal drawn from Sanborn maps, and a text from Italo Calvino's Invisible Cities

6) John Baldessari - (Los Angeles, 1931- ) a Conceptual/book artist since the mid-1960s, in The California Map Project, Part 1: CALIFORNIA (1969), Baldessari constructed the letters in the state's name on the ground as close as possible to the site the letters occupied on a National Geographic map, "to see the landscape as a map": 10, 17

7) Barford/Carter/Klauser - (London, 1977-, 1979-, 1977- ) are Barnaby Barford, Kirsty Carter, and Andre Klauser, made bar accessories that included, in an interesting projection, a battleship game-map napkin, which is about "playing battleships in a smart cocktail bar," in, needless to add, London: 16

8) Lane Barren - (LA, 1950- ) manipulates aerial photographs to propose utopian alternatives:

9) Carol Barton - (Maryland, 1954- ) makes art books out of and utilizing maps to deal with issues involving travel, space, and time: 14

10) Jake Barton - (New York, ...) has mounted Memory Maps on the Washington Mall; and City of Memory, WorldView, NY Observers on the Web; Digital Panorama for the City Museum of New York is a work in progress

11) Leo Saul Beck - $(\ldots, \ldots)$ makes three-dimensional topographic maps out of pieces of plywood cut to outline shapes found in the wood: $\mathbf{1 8}$

12) Lutz Becker - (London, 1941- ) does collages on maps related to his pre-war map of Berlin, and how it was working with that mental map while growing up in a city of ruins: "maps contain our natural or urban environment in precise measure, but also ... the changeable topography of our imagination": 16

13) Mark Bennett - (Los Angeles, ...) is a postal worker who makes maps of the settings of the sit-coms he's watched for years: $\mathbf{1 8}$

14) Lee Birkett - (London, 1972- ) stitches city plans and maps of places he has lived or visited on sheets and pillowcases: " the mapping of a city becomes a metaphor for the illogical sprawl of one's life": 16

15) David Bligh - (Chestnut Hill, Massachusetts, ...) draws places as models or maps for emotions and memory: 19

16) Joe Bodolai - (U.S. expatriate living in Canada, ...) compiled the survey of map artists in the artscanada issue devoted to map art, but is a Conceptual artist concerned with place in his own right, who uses maps as well: 2

17) Alighiero e Boetti - (Italy, 1940-1994) influential Arte Povera member, made a lot of maps, widely reproduced, mostly of the world, often with flag imagery, sometimes out of cloth; as well as gazetteers and other geographical work; including Duodeci formi di giugno (1967), in which he etched the outlines of territories on 10 June 1967, and a City of Turin (1968) in which he wrote the names at their residences of all the city artists known to him: 1 $(3 / 02), 7,10,11,12,17,18$

18) Ave Bonar - (Austin, 1948- ) is a photographer who uses maps to frame and contextualize her work, by pinning the photographs to maps as in her Photological Travel Map of the Western United States (1990) and/or by annotating the map as well as in her Clinton Farm Map (1994): 8

19) Veronique Bour - (Barcelona, 1968- ) makes collaged and painted maps of the world that portray movement: of birds, butterflies, intrepid adventurers: $\mathbf{1 6}$

20) Robert Bowers - (Toronto, 1945- ) a Conceptual artist concerned with place, and identified by Bodolai (which see) as one "whose work has been thoroughly pervaded with a consciousness of the issues of mapping," but without, as far as I can tell, making any maps, as in Detail (1969) or Search (1971): 2

21) Rolf Brandt - (London, 1906-1986) the brother of photographer Bill Brandt, in the 1970s "made a series of small collages using maps," in the form of, say, a person running: 16

22) Claude Breeze - (Canadian, ...) an important expressionistic landscape painter whose Canadian Atlas series pushed through more or less traditional 20th century landscape phases into one more strongly influenced by map iconography; with map imagery surging in his Town Corner series; and dominating in paintings like Canadian Atlas: Pearly Channel (1973): 2

23) Marcel Broodthaers - (Belgium? Germany?, 1924-1976) revised numerous maps to celebrate/make hash of the systematization of them all: $\mathbf{7 , 1 7}$ 
24) Stanley Brouwn - (Netherlands, 1935- ) a Conceptual artist, asked passersby to draw him maps to a given location which he assembled and published as a book, This Way Brouwn (Verlag Gebr. König, Köln-New York, 1961) among other participant map pieces: $\mathbf{2}, \mathbf{1 7}$

25) Jason Brown/Eddo Stern - (LA, 1970- , 1972- ) have made a textbased multi-user environment-fantasy based on a map of the LA freeway system that the user navigates as conditions change: 15

26) Tara T. Bryan - (Newfoundland, 1953- ) makes unique landscape art books combining images of landscapes with fragments of maps

27) David Bunn - (Los Angeles, 1950- ) works extensively with maps and map projections, making map-involved objects, photographs, paintings, and videos, as in Projection (1984) and The Torrid Zone (1987) : 8

28) Jane Bush - (London, 1955- ) makes collage maps: 16

29) Waltercio Caldas - (Brazil, 1946- ) in the early 1970s (at least) made maps of places by drawing hints of parts of outlines: the map of the place becomes no more "legible" than our image of the people living there: 7

30) Jonathan Callan - (London, 1961- ) works extensively with maps which he dismembers, frames, manipulates: $\mathbf{1 6}$

31) Joyce Campbell - (LA, 1971- ) a New Zealander currently working in LA, Campbell captures, on photosensitive paper the paths of bacterial colonies which she has cultured from samples of soil and organic matter collected from different LA neighborhoods: 15

32) Lewis Carroll - (English, 1832-1898) who was actually Charles Dodgson, made a map for The Hunting of the Snark, which was perfectly blank; also described maps made at a scale of 1:1 in Sylvie and Bruno: 18

33) Center for Land Use Interpretation - (LA, 19??- ) mounts elaborate exhibitions documenting, and road trips exploring, land use through photographs, maps, and other media (very cool outfit): 15

34) Mel Chin - (North Carolina, 1951) does installation map pieces such as Inescapable Histories (1988), about Palestine and Israel, and Degrees of Paradise: The State of Heaven (1991), about the Kurds, among others: $\mathbf{1 2}$

35) Christo and Jeanne-Claude - (New York, 1935- ) make environmental art projects involving maps as planning, fund-raising, approval, construction, and appreciation documents, from Valley Curtain (1970-72) through The Gates (1979-2005): 3, 4, 10, 17

36) Greg Colson - (California, 1956- ) has made maps of urban American street systems out of scrap wood, metal: they're reliefs or shallow sculptures: 7

37) Constant - (..., ...), an influential Dutch Situationist, made a map, New Babylonian Sectors Superimposed upon a Map of Amsterdam, c. 1963, which resembles in structure the maps Debord made with Asger Jorn: 11

38) Houston Conwill - (American, ...) in collaboration with Joseph de Pace and Estella Conwill Majozo, makes projects consisting of various large maps installed on floors and walls with photographs and other elements as in The New Cakewalk Humanifesto: A Cultural Libation (1989) and The New Merengue (1992): 13

39) Joseph Cornell - (New York, 1903-1972) used maps throughout his widely influential career in many series of his signature boxes: $\mathbf{1 2}$

40) Marlene Creates - (Newfoundland, 1952- ), often assimilated to a Hamish Fulton-Richard Long tradition, has been showing her "memory maps" at least since 1987 (then in Sault Ste. Marie); the "maps" consisting of photographs of older people at home, of actual maps they've drawn, of texts related to places on the maps, and of photographs of sites on the maps, often together with objects found at the site, most elaborately in her project The Distance Between Two Points Is Measured in Memories, Labrador 1988 , but other map art too

41) Susan Crile - ( ... ) switched from painting Oriental-rug subjects to aerial views of the earth in the 1970s: 5

42) Théodore Coulombe/Alan Krathaus - (Brooklyn/Houston, 1963- , 1968- ) work with air photos and maps to deal with issues of claims of conquest and actual control: 14

43) Greg Curnoe - (London, Ontario, ...) a former surveyor, makes all kinds of map art, including a map of North American excluding the U.S. for the cover of the Journal of Canadian Fiction (Winter, 1973): 2

44) Alasdair Currie - (Scotland, 1964- ) made an installation piece consisting of models of buildings on a map on cloth that explores Lee Harvey Oswald's memory, assuming Oswald to be alive and in an institution; about time, memory, obsession: 16

45) Matthew Cussick - (New York, ...) recently began working with discarded road maps in a painterly exploration which led to The Map Paintings which he showed at Kent Chelsea in 2004 - a cool catalogue is available with a "legend"

46) Layla Curtis - (London, 1975- ) makes maps that "invite us to consider such issues as disputed borders, international relations" and so on, in one example, by swapping countries, like China and the U.S.: 16

47) Salvador Dalí - (Spain, 1904- ) made a two-sheet collage called La Casamiento de Buster Keaton (The Wedding of Buster Keaton), dated November 1925, with five map fragments of the Sea of Japan, Greece, among other elements - it's in the possession of the Fundacíon Federico García Lorca, Madrid

48) Norman Daly - (...,...) made a map of Llhuros, an imaginary country (1972), which map appears in Michel de Certeau's essay in Helen Mayer and Newton Harrison's The Lagoon Cycle (Johnson Museum, Cornell, 1985); and which Wollen reproduces, essentially without comment: 11

49) Adam Dant - (London, 1967) made a lithograph in 2000 of Shoreditch as globe (or at least round map)/Globe (Theater): 16

50) Leila Daw - (Branford, Connecticut, ...) has been working with concepts of mapping in her painting and other manifestations since the early 1980s when she mapped native American sites in skywriting smoke over their former locations - now does large, map-based public art installations as the one at Bradley International: 19

51) Guy Debord - (France, 1931- ) immensely influential Situationist who, in addition to writing Society of the Spectacle and other Situationist polemics, made psychogeographic guides to Paris by pasting together cut-up tourist maps to create alternative narrative labyrinths organized by the body, by desire, with and without the collaboration of Asger Jorn: 7, 11, 17

52) Wim Delvoye - (Belgium, 1965- ) among much other stuff has made a series of over forty maps conflating geography and anatomy: 14, 18

53) Michael Decourcy - (Vancouver, ...) works with photographs and all sort of mapping techniques in pieces like The Atlas of Aerial View Regional Land Impressions of British Columbia (1973) and Background/Vancouver (1974): 2

54) Agnes Denes - (US, 1938- ) explores the issue of map distortion by projecting the surface of the globe onto, among other surfaces, a tangent torus (doughnut) and a helical toroid (snail): 3, 4, 6, 10, 11

55) Jan Dibbets - (Netherlands, 1941- ) makes sensory maps of the artist's experience of Holland as a flat, constructed place, mixing elements of artists like Ed Ruscha, Richard Long, and Marc Wise: $7,10,17$

56) $[$ Elizabeth] Diller + [Ricardo] Scofidio - (New York? ... ) etch a map of each state onto mirrors mounted in fifty open suitcases in their 1991 Tourisms: suitCase Studies, where the banality of the postcarded sentiments undercuts the specificity of the places etched onto the mirrors which let you read the postcards, in their Whitney retrospective: 1 (10/03), 13

57) Kim Dingle - (Los Angeles, 1951- ) unlike Kerry Tribe, who simply exhibits maps she has asked ordinary people to make for her, Dingle makes paintings based on maps she has asked ordinary people to make for her: 7, 8, 12, 18

58) Josh Dorman - (New York, ... ) makes landscape paintings, often "with color inks on antique maps" whose topography "is often an inspirational starting point": $1(3 / 04)$

59) Matilda Downs - (London, 1974- ) does etchings with titles like 
Map of Cow Markings, Weather Chart: Hurricane Paths, and Map of London - Animal Kingdom: 16

60) Margret Dreikausen - (New York, ... ) makes paintings of the earth from an aerial perspective inspired by her work as a flight attendant in the early 1960s; her book, Aerial Perception, was her master's thesis: 5

61) Michael Druks - (London, 1940- ) Israeli-born, Druks in his 1970s' Flexible Geography: My Private Atlas project, "use[d] international and visual language for individual purposes" to explore "borders and boundaries and their political implications": 16, 18

62) Marcel Duchamp - (French-American, 1887-1968) one of the twentieth century's dominant artists, made his widely-reproduced Allégorie de genre (1943), punning a map of the United States with the head of George Washington: 17

63) Gary Duehr - (Somerville, Massachusetts, ...) sepia tints large scale satellite imagery probing the intersection between nostalgia and homeland security, as in Topeka \#1 (2004): 19

64) Sam Easterson - (LA, 1972- ) basically works with the world seen (understood) from the perspective of animals but has made a map of Manhattan "constructed" from the viewpoint of a deer, a mouse, a fox, etc. around $1000 \mathrm{AD}$; also On the Farm: Live Stock Footage by Livestock at CLUI: $\mathbf{1 4}$

65) Tracey Emin - (London, 1963- ) wrote a poem about a war on a printed map: 16

66) Kate Ericson/Mel Ziegler - (US, 1955-1995, 1956- ) made installation art dealing with economics, history, politics, occasionally taking map form; it's been just Mel since Kate died: 14

67) Luciano Fabro - (Italy, 1936- ) made Road Map Italy out of lead and wood (1969) and Golden Italy out of gilt-bronze and steel cable (1971), as a participant in Arte Povera; and later a torch-cut a map of Germany out of plate steel in La Germania (1984), in a complicated installation piece/political commentary: 1 (3/02), 7

68) Öyvind Fahlström - (Brazil? Sweden? US?, 1928-1976) many of Fahlström's graphic/cartoon analyses of geopolitical situations may not be maps but plenty are; Storr acknowledges that his example is not strictly speaking a map but "an eccentric flow chart of international relations"; the same piece was exhibited in the Charles show in Abingdon; but the World Map (1972) in Harmon, and others, are absolutely maps: 3, 7, 9, 18

69) Simon Faithful - (London, 1966- ) made a computer map with an inkjet printer that revisualized the world: "What should be a tool to interpret the world has become untrustworthy; what was familiar is now skewed and strange": 16

70) Heide Fasnacht - (New York, 1951- ) made a floor piece as a thick map of Ohio with a hole where Columbus usually is and other complicated references: 7

71) Peter Fend - (New York, 1950- ) runs Ocean Earth Development Corporation which uses maps extensively to plan, develop, execute, and exhibit financeable outdoor earthworks as functioning "architecture," as in Ocean Earth: Europa (1991) and Ocean Earth: Oil Free Corridor (1993): 10

72) Dan Fern - (London, 1945- ) works with maps to explore memory, space, autobiography: 16

73) Vernon Fisher - (Fort Worth, 1943- ) uses blackboard slating as support for maps, graphs, and diagrams, as in Swimming Between Australia and Japan (1993) with its swimmer on a map of the Pacific mounted on slate on wood: 8

74) Jane Frank - ( ... ) dealt with the aerial view of landscape from the late 1960s through the mid-1970s, working on both day and night images: 5

75) Vera Frenkel - (Canadian, ...) works with maps and other spatiotemporal imagery in elaborate participatory installations such as Map with Gates (1973-74): 2

76) Glowlab $-(\ldots, \ldots)$ is an art collaborative involved in a variety of psychogeographic map work, including production of the psy. geo.CONFLUX, part festival, part conference

77) Hamish Fulton - (Britain, 1946- ) makes conceptual map art, usually taking the form of a "spatial" act caught in a photograph, but also as literal maps (resembling concrete poetry), not unlike that of his friend, Richard Long: 7, 10, 17
78) Birgit Gehrt - (Berkeley, 1969- ) among other things works cutting up maps in a manner similar to that pioneered by Nina Katchadourian: 15

79) General Idea - (Canada, formed 1969- ) made a map in 1987, A Mari Usque Ad Mare, which ran the blue color of the ocean right over Canada thus literalizing the motto on the country's coat of arms (allied in spirit to the exclusion of the US from the Surrealist map of the world, and Curnoe's North America): 6

80) Adam Gillam - (London, 1970- ) uses maps and mapping to explore his relationship to the places where he lives and works: 16 81) Joshua Glotman - (Israel, ...) made a map of Israel, but under camouflage, Untitled (1993): 13

82) Zbigniew Gostomski - (Poland, 1932- ) a Conceptual artist in whose work schemata and documentation played with spatial constructions to form self-reflexive commentary on art's boundaries, at least one of which was done on a map of Warsaw in 1970, Fragment of the System: 17

83) Nancy Graves - (New York, 1940- ) among other things, redraws moon maps, Nimbus satellite imagery, and other very high altitude aerial photography to make her influential drawings, paintings, and prints: 2, 3, 4, 5, 7, 12, 18

84) Hans Haacke - (New York, 1936- ) is concerned with physical and biological processes, but as well with their relation to economic systems; used maps, photographs ands other documentation in Shapolsky et al., Manhattan Real Estate Holdings (1971), and designed, for a competition, an architectural model, Calligraphie (1989), consisting of a thirty-some-foot wide map of France intended to be made up of seasonal crops grown in cycles, and others: 10, 13, 17

85) Jane Hammond - (New York? ... ) made a ten by eleven foot painting in the shape of Connecticut creating a complicated map of the state reminiscent of a certain genre of tourist maps, but with a more personal iconography: $1(9 / 97)$

86) Newton and Helen Mayer Harrison - (San Diego, 1932- , 1929- ) are ecologically self-conscious conceptual artists who have been making prominent use of maps in their art for years (for example their 1974 If This Then That (the First Four): San Diego as the Center of the World - which is a map mural - and their 1977 Meditations on the Condition of the Sacramento River, the Delta, and the Bays of San Francisco); Michel de Certeau's essay about them in The Lagoon Cycle is copiously illustrated with maps (Herbert Johnson Museum of Art, Cornell, Ithaca, 1985) while The Lagoon Cycle itself features numerous beautiful huge maps; as do Peninsula Europe; Casting a Green Net: Can It Be We Are Seeing a Dragon?; Krimpenerwaard; and A Vision for the Green Heart of Holland: $\mathbf{1}$ $(10 / 03), \mathbf{4}, \mathbf{1 0}, 11$

87) Mona Hatoum - (London? 1952- ) does other map art too, but in 2003 she remounted at LA MOCA her Map originally created for her one-person show in 1998 at the Kunsthalle Basel, consisting of 3,300 pounds of clear glass marbles in the form of the earth's landmasses on the floor of the museum "forcing us to question the stability of our world geography": 13

88) James Hayward - (Moorpark, California, 1943- ) uses streets maps of cities around the world to replace canvas as the traditional support for his paintings: $\mathbf{8}$

89) Michael Heizer - (Nevada, 1944- ) is an influential earthwork artist who uses maps in planning and documentation, and later as screen prints: $\mathbf{8}, \mathbf{1 0}$

90) Susan Hiller - (London, 1940- ) American-born Conceptual artist, did Dream Mapping (1974), in which ten participants slept three nights among fairy rings in Hampshire, recording their dreams each morning in map like diagrams which Hiller composed into Composite Group Dream Maps; Dedicated to the Unknown Artist, documenting tumultuous sea postcards using maps (among many other things); and so on: $4,17,18$

91) David Hinton - (Vermont, 1954- ) published Fossil Sky, an epic poem, lyrical map (54" x 54"), and Conceptual artwork (Archipelago Books, 2004)

92) Nancy Holt - (New York, 1938- ) does site-specific sculptural installations oriented to the paths of celestial objects, but see 
especially Buried Poems (1969-71) which consists of maps and instructions for finding poems she buried, accompanied by details of history, geology, maps, samples: 3, 4, 7, 10

93) Sharon Horvath $-(\ldots, \ldots)$ has long incorporated topographical imagery into her paintings: 18

94) Douglas Huebler - (New York, 1924-1997) a key Conceptual artist, began making maps in 1968, such as Site Sculpture Project $-42^{\circ}$ Parallel Piece (1968) and Site Sculpture Project - Variable Piece \#1, New York City (1968), in which the maps are pieces of Site Sculptures; his mapped Duration pieces (1968-?); as well as self-documentation pieces, such as Location Piece No. 1 (1969), Rochester Trip (?), and others which traced Huebler's routes through various environments: $4,8,10,11,17$

95) Abigail Hunt - (London, 1978- ) cut a map into two books which were then subjected to further manipulation: 16

96) John Hurrell - (Christchurch, New Zealand, ... ) paints on actual paper maps, most notoriously by using black paint to isolate clusters of streets, which up-close can be identified, but from farther away read as heads, angles, marching figures, a bizarre trope on the Surrealist game of l'une dans l'autre; and other map art

97) Robert Indiana - (American, 1928- ) made maps in his signature Pop art style, especially of the South during the years of the battles for civil rights: 12

98) David Ireland - (San Francisco, 1930- ) whose Three Attempts to Understand van Gogh's Ear in Terms of the Map of Africa is a pretty cool map version of seeing things in clouds: 7

99) Patrick Ireland - (US? 1928- ) is a pseudonym of Brian O'Doherty, an Irish protest artist who, in 1998 exhibited a reconfigured map of Ireland "in which Northern Ireland had been cut out and collaged over the Republic," cartographically recapitulating the unification $\mathrm{O}^{\prime}$ Doherty achieved in 1972 by covering his body with orange and green paint: 1 (5/99), 4,

100) Yvonne Jacquette $-(\ldots, \ldots)$ exploits a high oblique view of the landscape to make paintings that run from the nearly realistic to an almost Nancy Graves-like abstraction: 1 (3/04), 5

101) Alfredo Jaar - (New York, 1956 (Santiago, Chile) is an installation artist whose gallery-size La Géographie ça sert, d'abord, à faire la Guerre (Geography = War) (1989, and later installations) mounted large maps in light boxes, petroleum barrels, and photographs to talk about Africa, oil, and war. An interesting catalogue is Madeleine Grynsztejn, Alfredo Jaar, La Jolla Museum of Contemporary Art, La Jolla, 1990, which uses the Peters projection as its supervening graphic device; but also, with its many illustrations, Alfredo Jaar, Geography = War, Virginia Museum of Fine Arts, Richmond, 1991, with essays by W. Avon Drake, and others: 13,17

102) Jasper Johns - (New York, 1930- ) famously made maps of the U.S., but also one of the world using Buckminster Fuller's Dymaxion projection, as a mural for the Montreal Expo: 7, 8, 12, 17

103) Kim Jones - (New York, 1944- ) makes maps of the battles between the Dot Men and the X Men: 7

104) Ilya Kabakov - (New York, 1933-) is an installation artist who often works with themes related to his long life in the Soviet Union, but has also worked with maps, as in the seashore map in Anna Petrovna Has a Dream (1972-1975) and The Globe in a Different Environmental System (1999): 12

105) kanarinka [Katherine d'Agnasio] - (Waltham, Massachusetts, ..) works with maps and mapping in a variety of ways with Glowlab, The Institute for Infinitely Small Things, and so on

106) On Kawara - (New York, 1933- ) was originally Japanese, but moved to New York in 1965. A key Conceptualist, Kawara used maps in his series I Went (1968-1979) to diaristically trace his trajectories through given cities, as in I Went, 21 February 1969, I Went, Dec 25 1978, until the project was ended on 17 September 1979: 2, 4, 11, 17

107) Nina Katchadourian - (Brooklyn, 1968- ) makes very cool things made from maps by cutting and collaging, or by cutting out the backgrounds of street and road maps to leave spaghetti, displayed either as it comes from the pot, or carefully laid out between Plex: 14, 18
108) Tilman Kayser - (Germany? ... ) draws on imagery of the earth seen from space to make paintings with connections to abstract expressionist aesthetics: $\mathbf{5}$

109) Ellsworth Kelly - (New York, 1923- ) in 1950 redrew a regional map of France with strips of blue paper to indicate field lines to make Fields on a Map: 7, 18

110) Chris Kenny (London, 1959- ) stages encounters between maps and Mondrian by using strips cut from maps to rebuild Mondrian's transitional paintings of 1912-18, reversing Mondrian's move from the specific to the universal, and otherwise works with maps, as in his Fetish Map of London I (2000): 16,18

111) Yves Klein - (France, 1928-1962) in the 1960s made large-scale terrain-like maps, as he made clear by inscribing, on the back of Planétaire (Bleu), the phrase "planète-terre": 7, 17

112) Joyce Kosloff - (New York, 1942- ) Kosloff has paint frescoes based on ancient maps in her "Knowledge" series; she also deals with power, conquest, and bombing by restructuring maps and globes, including one huge, walk-in globe papered on the inside with target maps of places the U.S. has bombed since WWII (also the subject of elin slavick's work); recently produced Boys' Art, drawings of military maps with collaged fighting men: 1 (7/99), 12,14 ,

113) Guillermo Kuitca - (Argentina, 1961- ) makes map-paintings at scales covering apartment floor plans and the world, about himself and life: $\mathbf{7 , 1 8}$

114) Laura Kurgan - (New York, 1961) works extensively with GPS in her You Are Here series, and with satellite surveillance imagery as in Spot 083-264, June 3, 1999, Kosovo (1999): 12

115) Charles LaBelle - (Los Angeles, 1964- ) in his Invisible Cities (Abandoned Mattresses) project (1992-1993), LaBelle picked up mattresses from the streets of Los Angeles, took them to his studio where he painted on them the outlines of cities picked at random from a world atlas, returned the mattresses to where he found them, photographed them, and documented their location on a map; while his alter ego, Charles Bon, made a movie about it, Invisible Cities (Los Angeles) (1994); he also uses map flags stuck into pillows and his own body to simulate battle plans: $\mathbf{8}$

116) Charlotte Land (London, 1980- ) collected responses from randomly selected people about one day's journey in London and compiled them into an atlas, documenting the common grounds shared by people living individual and separate lives: $\mathbf{1 6}$

117) Langlands \& Bell [Ben Langlands and Nikki Bell] (English, ...) made a diptych Air Routes of Britain (Day) and Air Routes of Britain (Night) (2002): 18

118) Julian LaVerdiere - (New York? ... ) is interested in the cartographic representation and exercise of power, including in FIRMAMENT: Upon Which Time Has No Mark by Definition, for example, a 20-foot world map printed on Textalene, and making a print displaying the original and resolved UN logos: $1(6 / 03)$

119) Mark Lazenby (London, 1975- ) makes mixed-media collage maps - for example: "In Lost a boy is bewildered, utterly lost - the map makes no sense"

120) Annette Lemieux - (Massachusetts, 1957- ) pieced together air photos of the northeast US to make a scroll which she has emerging from a typewriter whose key caps have been replaced with cameo photos of terrain features, as though you could type up a landscape: 7

121) Jane Lewin $-(\ldots, \ldots)$ made a painting depicting meanders in a river, Rheidol Collage (nd), in color, which David Woodward reproduced in his Art and Cartography as his sole example of how "the mapping instinct" has "manifested itself in modern painting" after a list on which he included Escher, Johns, William Wiley, Christo, Oldenburg, Graves, Long, the Harrisons and others

122) Sol LeWitt - (Connecticut? 1928- ) is an influential Conceptual artist who in the 1970s cut simple shapes out of air photos of Manhattan according to a system he'd set up": 3, 7, 17

123) Micah Lexier - (New York, 1960- ) doesn't really deal with maps qua maps but with issues around our representation of time and experience, which may involve maps: $\mathbf{1 4}$ 
124) Lilla Locurto/Bill Outcault - (...,...) scan the surface of their bodies with a 3D object scanner, and use GeoCart map projection software to flatten their bodies out as though it were the earth

125) Mark Lombardi - (New York, 1951-2000) made elaborate diagrams charting flows of influence and money in many of the political/banking/military/terrorist scandals of the 1990s which many refer to as "maps" or claim Lombardi "mapped" the relationships of the parties involved (11/03)

126) Richard Long - (Britain, 1945- ) is an influential sculptor, earth artist, and conceptual map artist, who takes walks documented in photographs as well as on maps, e.g., No Where (1993), Four Days and Four Circles (1994), and Concentric Days (1996), and as maps, which may resemble concrete poetry as Urinating Places Line (1993), Circle of Autumn Winds (1994), Splashing Around a Circle (1997), Circle of Middays (1997), not unlike those of his friend, Hamish Fulton; and has also written "Notes on Maps 1994": 4, 7, $10,12,14,17,18$

127) Robin Mackenzie - (Canadian, ...) works in a vein generally related to that of Richard Long and Hamish Fulton, except it's more concerned with "declared space" - scale, grids: 2

128) Satomi Matoba (London and Hiroshima, 1960- ) Matoba seeks "to create a magical map that guides me out of this dislocation [of living in London and Hiroshima] and enables me to envisage a peaceful community of strangers; a map that shows the world differently" by manipulating maps with computers: 16

129) Gordon Matta-Clark - (New York, 1942-1978) is Roberto Matta's son who, in Realty Positions: Fake Estates (1973), purchased thirteen parcels of land "left over" after Queens was remapped and the property lines were redrawn, exhibited as deeds, site photos, and property maps; and done other map work: 10, 17

130) John McQueen - (Saratoga Springs, 1943- ) uses tree bark and leaves in traditional basket-making techniques to make big threedimensional sculptures of lakes and rivers, which are, after all, three-dimensional in volume: $\mathbf{1 4}$

131) Julie Mehretu - (Ethiopia, 1970- ) paints "story maps of no location": 18

132) Michael the Cartographer $-(\ldots, \ldots)$ an anonymous Outsider mapmaker collected by Victor Musgrave, a couple of whose maps are in the Musgrave-Kinley Outsider Collection in London: 18

133) John Miller - (New York, 1954- ) covered a globe he created "with the color of lustrous excrement": 7

134) Michael Barton Miller - (Los Angeles, 1949- ) makes paintings on supports shaped like the map of the city that is the subject, in some sense, of the painting: 8

135) Dan Mills - (Lewisburg, Pennsylvania, ...) paints maps/metaphors on wood as in New Venice (2003), in a series called US Future States: 19

136) Barbara Milot - (Turners Falls, Massachusetts, ...) draws landscapes in map form, such as Ribbon Map (2003): 19

137) Edwin Morgan - $(\ldots, \ldots)$ the Scottish concrete poet, made a map-poem, Chaffinch Map of Scotland (1965), by plotting the range of Scottish names for the chaffinch: 18

138) Satoshi Morita - (Germany, 1974- ) works with postcards and maps "to reveal the background of reality according to our perception of space": 16

139) Brian Moss - (LA, 1962- ) makes filmic-photograph performance maps as records of movement and behavior in a domain also explored by Marc Wise: 15

140) Lior Neiger - (Brighton, Massachusetts, ...) spins globes freely on paired video screens, stopping them randomly to create novel spatial encounters in Globe (2000): 19

141) Mariele Neudecker $-(\ldots, \ldots)$ had an exhibition in the summer of 1999 called "Never Eat Shredded Wheat" (Memory Maps) at the James Harris Gallery in Seattle

142) Joshua Neustein - (New York, ...) uses maps extensively to mount meditations on boundaries, including Territorial Imperative: Golan Heights (1970s?) which involves a dog urinating and maps of the many borders; Grid Over Europe (1987) Continental Tracker (1987); Germany Framed (1992), and many others: 13
143) N.E. Thing Co. [Iain Baxter/Ingrid Baxter] - (Vancouver, 19361938- ), or NETCO, was founded in 1966 and disbanded in 1978, but did things like Quarter Mile Landscape (1969) documenting the readymade landscape with photographs and maps: 17

144) Manuel Ocampo - (Los Angeles, ... ) parodied the Thomas Guide in his 1987 Untitled (Ethnic Map of Los Angeles) and carved the city into "occupied zones" of dykes, kikes, fags, chinks, nips, etc

145) Brian O'Doherty - see Patrick Ireland, but also: 17

146) Claes Oldenburg - (New York, 1929- ) in Soft Manhattan \#1 (Postal Zones) (1966), he made one of his trade-mark soft sculptures out of the assembled postal zones - looks sort of like a side of beef - but he also made Chicago Stuffed with Numbers (1977): 3, $7,12,18$

147) Anna Oliver - (Sussex, 1964- ) makes paintings of small sections of maps, of places represented in famous landscape paintings or, more recently, of places on war maps and again from other maps: 16

148) Yoko Ono - (New York, 1933- ) is an influential Conceptual artist who has done a number of map and globe pieces, most notoriously her Map Piece (1962) but also the more recent Imaginary Map Piece V (1999) and others: 11, 12, 17

149) Dennis Oppenheim - (New York, 1938- ) is a key Conceptualist who, working with a deep interest in space, and the idea that art may be a way of viewing rather than making something to be viewed (whereas a map is both?), used maps extensively to document and exhibit his work, but also drew the floor plan of galleries on the ground in Gallery Transplants (1969) and made an $X$ on ground mimicking that on a map in Relocated Burial Ground (1978): 2, 3, 4, 10

150) Nam June Paik - (New York, ...) made a map, FLUXUS Island in Décollage OCEAN (1963), one of a number of Fluxus maps (see Yoko Ono and Chieko Shiomi); and much later Electronic Superhighway (1995), in which televisions are embedded in a gigantic neon map of the United States (reproduced in Richard Leslie's Pop Art, Todtri, 1997): 11, 17

151) Cornelia Parker - (London, 1956- ) burns maps with a piece of red-hot meteorite to mark mythic sites (i.e., like Paris, Texas): 16

152) Lee Paterson - (London, 1955- ) makes maps of his walks in museums: 16

153) Simon Patterson - (Britain, 1967- ) in The Great Bear (1992), renamed all the Underground stops to form a constellation of earthly stars (e.g., Janet Leigh) in the disposition of a subway line, an so a map that is also concrete poetry: $7,13,18$

154) Raymond Pettibon - (California, 1957- ) did a drawing of the earth in a circle as seen from a point high over Buenos Aires with the with words "a flat landscape extending in all directions to immense distances placates me" written on it: 7

155) Danica Phelps - (Brooklyn, ...) uses maps in a variety of ways in her complex documentary activities: 1 (7/99, reviews)

156) Tom Phillips - (London, 1937- ) made Mapwalk in 1972/3 (which finds Nasca-like glyphs in the London street pattern by blacking out irrelevant streets; he's also made Humument Globes and an Extra-terrestrial Globe (1992), and has referred to his "early desire to be a cartographer (for at school I always enjoyed mapmaking especially when drawing Scandinavian countries where I could improvise intricate fjords"

157) Adrian Piper - (Massachusetts, 1948- ) worked in an earthworks mode early in her career, in the process of which she produced documentary and presentation maps; and proposed orientation/ map projects in a Nancy Holt vein: 7,17

158) Platform - (London, founded 1983- ) is dedicated to "provok[ing] desire for a democratic and ecological society," as in their Still Waters (1992) project about unearthing London's buried Effra River: 10

159) Kathy Prendergast - (Ireland, ...) made the map, Lost (1999) of the United States incorporating only places with "Lost" in their name: $\mathbf{1 8}$

160) Margaret Proudfoot - (London, 1961- ) modified an atlas by taking a bite out of its spine to "reintroduce the third dimension into 
a map of the world": $\mathbf{1 6}$

161) Marek Ranis - (Charlotte, ...) makes large paintings of bombing sites derived from imagery taken from cameras on military aircraft (2002); also tents with satellite imagery on them as installations/sculptures (installed in Cape Town, 2004)

162) Michael Rees - (Cornwall, 1962- ) uses/makes maps on canvas "concerned with how a place forms you"

163) Julia Ricketts - (Seattle, ...) often makes paintings of landscapes from a very high oblique perspective with other map elements added: 18

164) Miguel Angle Ríos - (New York, 1943- ) works with early modern maps to meditate on the Columbian encounter: 7,12

165) Larry Rivers - (New York, 1923-2002) Africa I walks a line between Abstract Expressionism and Pop Art. Map like elements can also be found in some of his other work.

166) Laura Robinson/Leslie Kneisel - (Georgia? 1952- , 1952- ) put together the extremely ambitious Mappamundi (1993-1994) for the Albany Museum of Art (Albany, Georgia), but which went on to play Pittsburgh, Johnstown (Pennsylvania), and Altoona, a map and history of the world filtered through imagery collected on the artists' 12,000 mile trip around the US in 1992

167) Lordy Rodriguez - (Houston, 1976- ) repaints maps of subjects like New York, Wyoming, and the United States according to his desires and experiences: 14, 18

168) Charles Ross $-(\ldots, \ldots)$ coming from a scientized background like Graves, Ross uses drawing, painting, collage, and other techniques to make "solar burns," map-calendars and star maps, often shaping and cutting into the surface to mimic the idea of gores: $\mathbf{3}, \mathbf{4}, \mathbf{5}$

169) Marina Roy $-(\ldots, \ldots)$ includes three maps in her art book sign after the $X$ _ (Advance/Artspeak, Vancouver, 2001)

170) Ed Ruscha - (LA, 1937- ) made strip books like Every Building on the Sunset Strip which may not be maps, but are visualizations from which spatial narratives can emerge; and drawings and paintings of intersections which are indubitable maps: 14, 17, 18

171) Georgia Russell - (Paris, 1974) uses a scalpel to cut away parts of maps à la Katchadourian, though Russell displays the spaghetti in bell jars: $\mathbf{1 6}$

172) Mark Schafer - $(\ldots, \ldots)$ showed map collages under the title Invented Maps, Imaginary Landscapes in 2001 at the Globe Corner Bookstore in Harvard Square, including Shortcut: Boston-L.A./ N.Y.C.-San Diego," but also United States and Shortcut BostonMexico City (1994): 19

173) Paula Scher $-(\ldots, \ldots)$ began painting small, opinionated maps in the early 1990s, since when they've grown larger and larger and more obsessive: 18

174) Joe Scotland - (London, 1978- ) makes stitched and patchwork maps that "re-work the conventional classification of places" and "attempt to reveal the constructed qualities of maps, being simultaneously representations and objects": 16

175) Maura Sheehan - (New York? ... ) made Geography Lesson (1990), a piece commissioned by Virginia Commonwealth University in which Sheehan "in defiance of traditional cartography" painted maps (on old retractable movie screens) that were "upsidedown"; and other work: 1 (4/94), 9

176) Chieko Shiomi - (Osaka, 1938- ) was a Fluxus artist who used maps in her two Spatial Poems $(1965,1966)$ to record the locations of everyone who wrote a word or words on cards that she distributed: 11, 12, 17

177) elin O'Hara slavick - (Chapel Hill, ... ) has been working on a series called Places the United States Has Bombed consisting of aerial views of bomb targets or bombed sites

178) Susanne Slavick - (Pittsburgh, ...) has been working with maps from a feminist perspective since 1980

179) Jaune Quick-to-See Smith - (Salish and Kootenai Nation, ...) painted the United States à la Johns over a collage of clippings about native Americans' lives in Indian Country Today (1996): 12, 18

180) Robert Smithson - (US, 1938-1973) worked with/made maps at a variety of scales of a variety of phenomena, often but not al- ways in preparing/documenting his earthworks. He constructed The Map of Broken Glass (Atlantis) [1969] (also known as Map of Clear Broken Glass Stripes, and The Map of Glass (Atlantis)) in the Jersey Meadowlands; and he taught/wrote about his Non-site pieces as "three-dimensional maps": 4, 7, 10, 17

181) Michael Snow - (Canadian, ...) makes projections of things like logs and ladders, but also works with air photos: 2

182) Naomi Spellman - (LA, 1964- ) in 1999 had an exhibit at Harvard called, "GIS, Art, and the Harvard Map Collection"; and showed at SCI-Arc in 2002 doctored maps mapping the landscape onto the human body: $\mathbf{1 5}$

183) Mike and Douglas Starn - $(\ldots, \ldots)$ have made an enormous globe, Spheres of Influence (1990-92) out of tar, steel, maps, etc.; as well as other work using star charts and other exotic imagery: 12

184) Olivia Streeton - (London, 1973) makes mixed media constructions with titles like Map for Situation Room: 16

185) Henry Stein - (San Antonio, 1951- ) covers the surfaces of shovels and saw blades with brightly colored maps in his ongoing Map Tools series, and makes assemblages with globes as in Sound Barrier (1994) : 8

186) Patty Stone - (Newton, Massachusetts, ...) does paintings based on flight maps inherited from her father as in Flight Path 3 (2003): 19

187) The Surrealist Map of the World, or Le monde au temps Surréalists was published in a special issue, "Le Surréalisme en 1929," of the Brussels journal, Variétés, June 1929, pp. 26-27. The artist of this widely reproduced map is unknown. For a map which similarly elidesthe U.S., see Greg Curnoe's cover for the Journal of Canadian Fiction, but also General Idea's related map of Canada: 18

188) Louise van Swaaij and Jean Klare - $(\ldots, \ldots)$ produced their Atlas of Experience (Bloomsbury, New York, 2000): 18

189) Paul Tecklenberg - (London, 1969- ) makes map photograms of the northern lights and the aurora: 16

190) Fiona Templeton $-(\ldots, \ldots)$ a Conceptualist, used maps almost like a script to produce You - The City (1988), an interactive performance piece realized in a number of cities; the first realization was You - The City, Manhattan Itinerary (May-June 1988): 11

191) Valerie Tevere - (New York, 1970- ) in 2001 exhibited something called Mapping Memory at the Vacany Gallery in the Bronx; and in 2002 a video installation at SCI-Arc called, Palm Trees on Madison Avenue/A New York Mapping of Los Angeles, which consisted of responses to her questions to New Yorkers about LA, investigating the cultural production of the meaning of place: 15

192) Andrea Thompson - (Medford, Massachusetts, ...) makes constructions, mixing narrative potentials with interchangeable base maps, as in Then and There (2004): 19

193) Lincoln Tobier - (Los Angeles, ... ) constructs models of "place in concentrated form," as giant panorama models of Tokyo and Los Angeles - Panoptiramicon (1998) and (It all comes together in) Ruckus L.A. (1999 and continuing); and involved with short-term radio stations that Tobier creates to re-imagine, integrate, and intervene in intimate and official geographies, subjective and objective representations of public space

194) Joaquín Torres-García - (Uruguay, 1874-1949) the Uruguayan Constructivist, made a map of South America with south up for his La escuela del sur in 1943: 7,18

195) Kerry Tribe - (LA, 1973- ) prompts ordinary people to draw maps which she then frames and exhibits, as of LA drawn by people at LAX: 15

196) R. Gregor Turk - (..., ...) in 1992 walked and bicycled the 1,270 mile US-Canadian border west of Lake of the Woods to produce the 49th Parallel Project, an ambitious multimedia work in which maps of the parallel have been sliced, diced, collaged, and blownup to help explore the idea of borders

197) James Turrell - (Los Angeles, 1943- ) is essentially concerned with light, but this has led him to the Rodan Crater project (1977present; material - "volcanic mountain") which involves maps. John Beardsley reproduces one of Turrell's meticulous maps in Earthworks and Beyond (Abbeville, New York, 1984), p. 38; and Kastner and Wallis (see source list) his statement, "Mapping 
Spaces," pp. 219-220: 10

198) Adriana Varejão - (Brazil, 1964- ) makes paintings of maps that include gaping wounds or incisions as if the earth were living: 7

199) Bill Vazan - (Montreal, ...) a Canadian artist, primarily makes large-scale drawings on the land, but also works with maps and air photos, as in his Worldline (1969-71), Contacts (1971-73), and Regina Life Lines - 9 Mind Mappings (1980-81), tractor tire impressions, 5000' x 3000' feet: 2,4

200) Carmela Venti - $(\ldots, \ldots)$ seems to work in a variety of map genres: in 1994 she had a show at the Chicago Cultural Center in Chicago of works in an Yvonne Jacquette mode (Art on the Map); whereas earlier that year she showed reverse-silhouettes of heads filled with different maps at Bradley International Airport (Map Portraits: the traveler)

201) Jugoslav Vlahovic (Belgrade, 1949- ) as a member of Team A3 in 1974 made and documented the World Cow, a world map painted on a cow: 16

202) Deborah Waimon - (New Milford, Connecticut, ...) overprints fragments of maps from the 1950s to the present with small collagraph plates, as in Cartography XVII (2002): 19

203) Jason Wallis-Johnson (London, 1966- ) constructs/draws/and otherwise produces maps of places over time, imaginary cities, interventions in cities and so on: $\mathbf{1 6}$

204) Roberts Watts - (New York, 1923- ) made the Fluxatlas (19731978): 12

205) William Wegman - (..., ...) makes elaborate "scrapbook-maps" utilizing paint and found postcards: 18

206) Lois Weinberger - (Vienna, 1947- ) who is known for his work with ruderals (plants that grow back when the natural cover has been disturbed by humans) developed, in Course/Drift (2001), a map of a fictitious geography (MASS MOCA)

207) Simon Wells (London, 1955- ) erases, white-outs, and otherwise interferes with $A-Z$ of Londons: 16

208) Heidi Whitman - (Boston, ...) has been working on a series, Brain Terrain, that mixes other reference systems with maps as in Cartographer's Daydream/Brain Terrain \#87 (2004): 19

209) William Wiley - (Canada, ...) a painter working with map imagery, as well as concerned with the role of view in his work as, for example, in How to Chart a Course (1971): 2

210) Emma Williams (London, 1976- ) makes oil paintings of maps and/or of maps cum panoramas of London: $\mathbf{1 6}$

211) Chris Wilson (Northern Ireland, 1959- ) in such pieces as Map, River, and Landscape (all 2002) deconstructs maps in mixed media and in map and crayon on board: $\mathbf{1 6}$

212) Kevin Wilson - $(\ldots, \ldots)$ makes map paintings based on atlases and AAA documents of places with personal significance to him: 18

213) Marc F. Wise - (Brooklyn, 1964- ) makes complicated videomap collations dealing with his experience on the subway and elsewhere: 14

214) David Wojnarowicz - (New York, 1954-1992) used maps in paintings and sculpture throughout his brief career. He frequently painted on maps, but he also used them to collage mannequin of men and boys (Untitled [Burning Child], 1984), sharks (Untitled [Shark], 1984), and even globes (a world globe painted black, except for U.S.-shaped vignettes opening over Africa, Europe, and so on [Globe of the United States, 1990])

215) Adolf Wölfl - (Switzerland, 1864-1930) the Swiss Outsider artist, made maps as part of the imaginary life story he told in From the Cradle to the Grave: $\mathbf{1 8}$

216) Denis Wood - (North Carolina, 1945- ) makes maps at very large scale of Boylan Heights, the neighborhood he lived in for 23 years, of different aspects: of the stars you can see, of sidewalk graffiti, of underground pipes, etc.: 14,18

217) Yukinori Yanagi - (Japan, ...) made a map of the U.S., Broken Glass on Map (1996), out of glass shards from the window of a room at Alcatraz shattered, possibly during the siege of the $\mathrm{Na}$ tive Americans who occupied Alcatraz in 1969, whose shards, negating the state boundaries, alluded to the broken promises

218) Marina Zurkow/Scott Patterson/Julian Bleecker - (New York,
... ) created PDPal in 2003 for the Walker Art Center as a public art mapping application for the Palm PDA and the web to transform your everyday activities into a dynamic city that you write

\section{Sources}

$\mathbf{1}=$ published in Art in America, month and year in parentheses

2 = inclusion in On Maps and Mapping: artscanada 188/189, Spring, 1974

3 = inclusion in Peter Frank, curator, Mapped Art: Charts, Routes, Regions, Independent Curators, New York, 1981 (only a couple of entries from which have been included in the catalogue - see the note following this list of sources)

4 = inclusion in Lucy Lippard, Overlay: Contemporary Art and the Art of Prehistory, Pantheon, New York, 1983, on Conceptual, earth works, Eco, and other art of the 1960s and 1970s

5 = inclusion in Margret Dreikausen, Aerial Perception: The Earth as Seen from Aircraft and Spacecraft and Its Influence on Contemporary Art, Art Alliance Press, Philadelphia, 1985

$\mathbf{6}=$ inclusion in Ibor Holubizky, curator, Curatorial Project \#7: Atlas, Hamilton Art Gallery, Hamilton, Ontario, 1991

7 = inclusion in Robert Storr, Mapping, Museum of Modern Art, New York, 1994

8 = inclusion in Frances Colpitt, Mapping, UTSA Art Gallery, University of Texas at San Antonio, 1994

$\mathbf{9}=$ inclusion in Kathryn Charles, curator, Mapping Lessons, William King Regional Arts Center, Abingdon, Virginia, 1996

$\mathbf{1 0}=$ inclusion in Jeffrey Kastner and Brian Wallis, eds., Land and Environmental Art, Phaidon, London, 1998

$\mathbf{1 1}$ = inclusion in Peter Wollen's article, "Mappings: Situationists and Conceptualists," in Michael Newman and Jon Bird, eds., Rewriting Conceptual Art, Reaktion, London, 1999, pp. 2746

12 = inclusion in Robert Silberman, curator, World Views: Maps \& Art Frederick R. Weisman Art Museum, University of Minnesota, Minneapolis, 1999

13 = inclusion in Irit Rogoff, Terra Infirma: Geography's Visual Culture, Routledge, London, 2000

14 inclusion in Ian Berry, curator, the World according to the Newest and Most exact Observations: Mapping Art + Science, Tang Teaching Museum, Skidmore College, Saratoga Springs (NY), 200115 = inclusion in Lize Mogel and Chris Kahle, curators, Genius Loci, SCI-Arc Gallery, Los Angeles, 2002

16 = inclusion in England \& Co.'s exhibition, The Map is Not the Territory part ii, 2002, catalogue written and edited by Jane England

17 = inclusion in Peter Osborne, ed., Conceptual Art, Phaidon, London, 2002

18 = inclusion in Katherine Harmon, You Are Here: Personal Geographies and Other Maps of the Imagination, Princeton Architectural Press, New York, 2004

19 = inclusion in Elli Crocker, curator, Mapping: An Exhibition: Metaphor, Artistic Strategy, Graphic Device, Schiltkamp Gallery, Clark University, 2005

NOTE: We have seen only the first few pages of the catalogue of curator Peter Frank's Mapped Art: Charts, Routes, Regions (Independent Curators, New York, 1981). These indicate that it was a most comprehensive show, the rest of whose artists need to be added to this catalogue.

There are other shows not even a page of whose catalogues have been seen, including, Artists' Maps, at the Philadelphia College of Art, in 1977; that same year there was also a show, Maps, at the Art Lending Services Gallery of the Museum of Modern Art; in 1978 there was a show we believe was called Mapped Art at the now defunct Nobe Gallery in New York.

Again, all additions, corrections, emendations, and suggestions, including copies of the catalogues just named, are more than welcome, and may be addressed to either of the editors or any of the authors. 
